\title{
EVALUATION OF FUNGICIDES ON FUNGI ASSOCIATED WITH FRUIT ROTS AND LEAF SPOTS OF BRINJAL
}

\author{
M.T. AKTAR, K.S. HOSSAIN ${ }^{1}$ AND M.A. BASHAR* \\ Department of Botany, University of Dhaka, Dhaka-1000, Bangladesh \\ Key words: Fungicides, Fruit rot, Leaf spot, Brinjal
}

Different fruit rots and leaf spots have destructive impact on the production of brinjal which occur almost all brinjal growing countries in the world including Bangladesh ${ }^{(1,2)}$. The present work was aimed to find out suitable fungicide(s) following poison food technique $^{(3)}$ in vitro against the fungi found associated with these diseases.

Infected brinjal fruits and leaves were collected from the selected fields of BADC in Gazipur, fields at Sibpur village in Natore and Botanical Garden in the Dhaka University. Fungi were isolated from these infected plant parts following Tissue planting method on PDA. Among the isolates, Colletotrichum sp., Curvularia lunata (Wakker) Boedijn, Fusarium moniliforme Sheld., F. oxysporum Wollenw., F. semitectum Berk. \& Ravenel and Phomopsis $\mathrm{sp}$. were selected as the test fungi owing to their higher per cent frequency and previous reports ${ }^{(4,5)}$.

Six fungicides with different active ingradients viz., bavistin 50WP (50\% carbendazim), dithane M-45 (80\% mancozeb), Mc sulphur 80WP (80\% sulphur), ridomil gold MZ 68 WP (64\% mancozeb and 4\% metalaxyl), salcox 50WP (50\% cupper oxichloride) and tall 25EC (25\% propiconazole) were collected. By using PDA medium, their growth inhibition efficacy were evaluated against the above mentioned test fungi at $500 \mathrm{ppm}$ concentration on the basis of its active ingredient. An efficiency gradient was prepared on the basis of their complete inhibition ability first and after that, their higher average inhibition ability. Considering efficiency gradient three best inhibiting fungicides were selected to evaluate their fungitoxicity at 50, 100, 200 and 400 ppm concentrations against the test fungi. Three replications were maintained in each case. The inoculated plates were incubated at $25 \pm 2^{\circ} \mathrm{C}$. The radial growth of the colonies was measured at the fifth day of incubation. The per cent growth inhibition of each test fungi was calculated by using the formula of Hossain and Bashar ${ }^{(3)}$. The results were statistically analyzed by ' $t$ ' test following Steel and Torrie ${ }^{(6)}$.

Table 1 reveals that all the fungicides inhibited the growth of the test fungi partially or completely at $500 \mathrm{ppm}$ concentration. Out of six fungicides, tall, bavistin and ridomil were able to check the growth of Fusarium oxysporum completely. Similar findings were also reported on other fungi ${ }^{(7,8)}$. Tall also inhibited the radial growth of F. moniliforme,

*Author for correspondence: <botanybashar@yahoo.com>. ${ }^{1}$ Department of Botany, Jagannath University, Dhaka-1100, Bangladesh. 
Phomopsis sp. and Curvularia lunata completely. Bavistin also completely checked the mycelial growth of F. moniliforme and Colletotrichum sp.

Table 1. Fungitoxicity of fungicides against the growth of the test fungi at $500 \mathrm{ppm}$ concentration.

\begin{tabular}{lccccccc}
\hline \multirow{2}{*}{ Name of fungicides } & \multicolumn{7}{c}{ \% inhibition of radial growth of the test fungi } \\
\cline { 2 - 8 } & Fo & Fs & Fm & Ph & Co & Cu & Avg. \\
\hline Bavistin DF & $100.0^{\mathrm{a}}$ & $89.09^{\mathrm{a}}$ & $100.0^{\mathrm{a}}$ & $86.86^{\mathrm{a}}$ & $100.0^{\mathrm{a}}$ & $89.65^{\mathrm{a}}$ & 94.27 \\
Diathane M-45 & $96.92^{\mathrm{a}}$ & $87.27^{\mathrm{a}}$ & $98.55^{\mathrm{a}}$ & $96.07^{\mathrm{a}}$ & $96.9^{\mathrm{a}}$ & $94.82^{\mathrm{a}}$ & 95.02 \\
Mc Sulphur 80WP & $68.38^{\mathrm{a}}$ & $69.9^{\mathrm{b}}$ & $76.37^{\mathrm{a}}$ & $68.62^{\mathrm{b}}$ & $38.59^{\mathrm{a}}$ & $76.37^{\mathrm{b}}$ & 66.24 \\
Ridomil MZ Gold & $100.0^{\mathrm{a}}$ & $100.0^{\mathrm{a}}$ & $94.20^{\mathrm{b}}$ & $97.25^{\mathrm{a}}$ & $100.0^{\mathrm{a}}$ & $91.37^{\mathrm{a}}$ & 97.14 \\
Salcox 50 WP & $84.00^{\mathrm{b}}$ & $85.45^{\mathrm{b}}$ & $89.85^{\mathrm{c}}$ & $92.15^{\mathrm{a}}$ & $82.96^{\mathrm{b}}$ & $83.27^{\mathrm{a}}$ & 86.28 \\
Tall 25 EC & $100.0^{\mathrm{a}}$ & $92.72^{\mathrm{a}}$ & $100.0^{\mathrm{a}}$ & $100.0^{\mathrm{a}}$ & $94.73^{\mathrm{a}}$ & $100.0^{\mathrm{a}}$ & 97.91 \\
\hline
\end{tabular}

Efficiency gradient: Tall $>$ Bavistin $>$ Ridomil $>$ Diathane $>$ Salcox $>$ Mc sulphur. $a, b$ and $c$ indicate significance at $p=$ 0.001, 0.01 and 0.05 , respectively. $\mathrm{Fo}=$ Fusarium oxysporum, $\mathrm{Fs}=F$. semitectum, $\mathrm{Fm}=F$. moniliforme, $\mathrm{Ph}=$ Phomopsis sp., $\mathrm{Co}=$ Colletotrichum sp., $\mathrm{Cu}=$ Curvularia lunata and Avg.= Average.

Table 2 shows that tall checked mycelial growth of Fusarium oxysporum and Phomopsis sp. completely at all the tested concentrations. In case of $F$. moniliforme and Curvularia lunata it did the same only at $400 \mathrm{ppm}$ concentration. Bavistin checked F. oxysporum and Colletotrichum sp. completely at all the tested concentrations, but it did the same against F. moniliforme at $400 \mathrm{ppm}$ concentration. Similar observations have also been reported for other fungicides ${ }^{(9)}$. Ridomil inhibited Colletotrichum sp. completely only at 400 ppm.

Table 2. Fungitoxicity of three fungicides against the growth of test fungi at different concentrations.

\begin{tabular}{|c|c|c|c|c|c|c|c|c|c|c|c|c|}
\hline \multirow{3}{*}{$\begin{array}{l}\text { Test } \\
\text { fungi }\end{array}$} & \multicolumn{12}{|c|}{$\%$ inhibition of radial growth of test fungi at different concentrations (ppm) } \\
\hline & \multicolumn{4}{|c|}{ Bavistin $50 \mathrm{WP}$} & \multicolumn{4}{|c|}{ Tall 25 EC } & \multicolumn{4}{|c|}{ Ridomil MZ gold } \\
\hline & 50 & 100 & 200 & 400 & 50 & 100 & 200 & 400 & 50 & 100 & 200 & 400 \\
\hline Fo & $100^{\mathrm{a}}$ & $100^{\mathrm{a}}$ & $100^{a}$ & $100^{\mathrm{a}}$ & $100^{\mathrm{a}}$ & $100^{\mathrm{a}}$ & $100^{\mathrm{a}}$ & $100^{\mathrm{a}}$ & $57.7^{a}$ & $67.16^{\mathrm{a}}$ & $74.34^{\mathrm{a}}$ & $84.16^{\mathrm{a}}$ \\
\hline Fs & $61.63^{\mathrm{b}}$ & $69.71^{b}$ & $71.73^{\mathrm{b}}$ & $80.67^{a}$ & $61.87^{a}$ & $69.37^{a}$ & $71.05^{a}$ & $88.37^{a}$ & $67.24^{\mathrm{a}}$ & $75.24^{a}$ & $80.0^{a}$ & $92.38^{\mathrm{a}}$ \\
\hline $\mathrm{Fm}$ & $68.88^{a}$ & $78.44^{\mathrm{b}}$ & $82.88^{a}$ & $100^{a}$ & $65.67 \mathrm{a}$ & $75.02^{\mathrm{a}}$ & $80.86^{a}$ & $100^{a}$ & $77.16^{\mathrm{a}}$ & $81.16^{a}$ & $84.33^{a}$ & $87.84^{\mathrm{a}}$ \\
\hline $\mathrm{Ph}$ & $57.17^{a}$ & $68.81^{a}$ & $71.23^{\mathrm{a}}$ & $80.15^{a}$ & $100^{\mathrm{a}}$ & $100^{\mathrm{a}}$ & $100^{\mathrm{a}}$ & $100^{a}$ & $63.29^{a}$ & $71.88^{a}$ & $75.48^{\mathrm{a}}$ & $89.53^{a}$ \\
\hline Co & $100^{a}$ & $100^{a}$ & $100^{a}$ & $100^{a}$ & $61.82^{a}$ & $72.50^{a}$ & $76.23^{a}$ & $87.74^{a}$ & $69.23^{a}$ & $79.48^{a}$ & $82.05^{a}$ & $100^{a}$ \\
\hline $\mathrm{Cu}$ & $28.94^{\mathrm{c}}$ & $42.10^{\mathrm{b}}$ & $60.52^{\mathrm{b}}$ & $76.31^{b}$ & $70.50^{a}$ & $79.41^{\mathrm{a}}$ & $82.35^{a}$ & $100^{a}$ & $57.85^{a}$ & $61.85^{\mathrm{a}}$ & $69.69^{a}$ & $88.23^{a}$ \\
\hline Avg. & 69.44 & 76.51 & 81.06 & 89.52 & 76.64 & 82.72 & 85.08 & 96.02 & 65.41 & 72.8 & 77.65 & 90.36 \\
\hline
\end{tabular}

Efficiency gradient: Tall 25 EC > Bavistin 50WP> Ridomil MZ gold at 400 ppm. Letters and abbreviations are same as in table 1.

In an average, all the three fungicides inhibited all the test fungi best at $500 \mathrm{ppm}$ concentration. The present study suggests that tall $25 \mathrm{EC}$ may be exploited in vivo to control the test fungi associated with fruit rots and leaf spots of brinjal. 


\section{References}

1. Ashrafuzzaman H 2006. Udvid Rog Bighan. Bangla Academy, Dhaka-1000, Bangladesh, pp. 260.

2. Sundaresan RVS, S Kanagasundaran and A Sivapalan 1986. Studies on the fruit rot diseases of brinjal (Solanum melongena L.). Vignanam J. Sci. 1(1) : 26-28.

3. Hossain KS and MA Bashar 2011. In vitro effect of plant extracts, fungicides and antibiotics on the fungal isolates associated with damping-off disease of crucifers. J. Agrofor. Environ. 5(2): 17-20.

4. Anonymous 1997. Studies on fungal diseases of brinjal (Solanum melongena L.) occurrence in Chittagong district. An M.Sc. thesis, Department of Botany, Chittagong University, Bangladesh.

5. Pandey A 2010. Studies on fungal diseases of eggplant in relation to statistical analysis and making of a disease calendar. Recent Res. Sci. Tech. 2(9): 01-03.

6. Steel RGD and JH Torrie 1960. Principles and Procedures of Statistics. Macgraw Hill Book Co., New York p. 481.

7. Sharma RL 2006. Efficacy of fungicide impregnated paper liners against storage rot of tomato fruit. J. Mycol. P. Pathol. 26(2): 310-311.

8. Banyal DK, V Mankotia and SKK Sugha 2008. Integrated management of tomato collar rot caused by Sclerotium rolfsii. J. Mycol. P. Pathol. 38(2): 165-167.

9. Bashar MA 1992. Laboratory evaluation of some pesticides on Fusarium oxysporum f. sp. ciceri causing wilt of chickpea. Bangladesh J. Bot. 21(1): 157-159.

(Manuscript received on 18 December, 2013; revised on 29 December, 2013) 